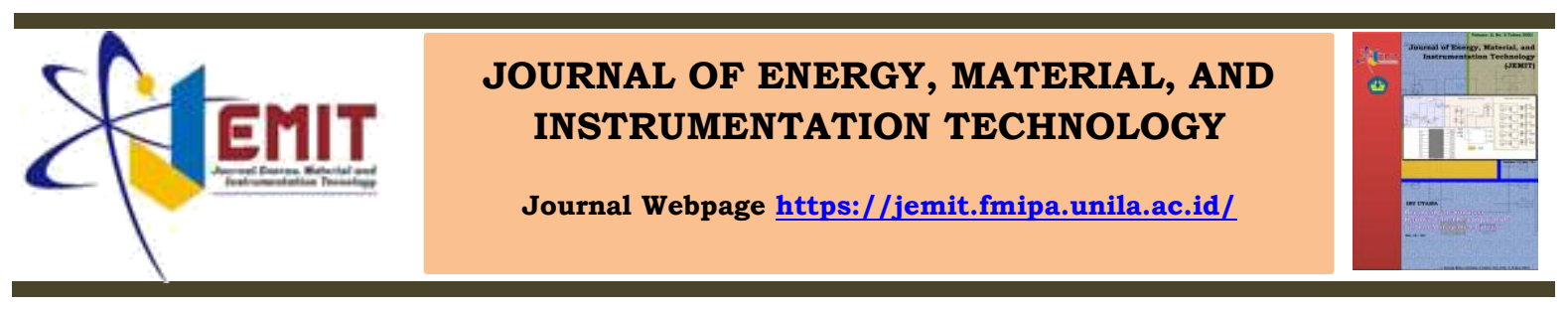

\title{
Perancangan Simulasi Hardware-In-The-Loop Untuk Sistem Manajemen Baterai
}

\author{
Muhammad Fathir*, Reza Fauzi Iskandar, Indra Wahyudin Fathonah \\ Jurusan Teknik Fisika, Universitas Telkom, Kota Bandung, Indonesia, 40257
}

\section{Article Information}

Article history:

Received August 19th 2021

Received in revised form

August 24th, 2021

Accepted August 29th, 2021

Keywords: Battery Management System, Bidirectional Converter, Cell Balancing, DC Microgrid, Hardware-in-the-Loop

\begin{abstract}
In a Microgrid system that relies on renewable energy generation, one of the most important constituent systems is the Battery Energy Storage System because of its vital role in maintaining the stability of the Microgrid in providing power to the load. However, to operate the battery, a Battery Management System is needed to ensure the battery operates at the desired working range, so that battery reliability can be maintained. To determine the behavior of the Microgrid and the designed BMS in accordance with the desired specifications, a Hardware-intheLoop (HIL) Simulation has been designed using Simulink to model a DC Microgrid which consists of several sub-systems such as: An ideally designed generator and load as a tester, a bidirectional buck and boost converter with a PI controller, and a battery system equipped with a Switched Shunt Resistor Cell Balancing type, all controlled using the BMS algorithm implemented on Arduino. From the test results, it is found that HIL can communicate with good QoS on various inputs as long as the Arduino sample time meets. Then the PI controller with HIL was able to improve converter performance and also succeeded in controlling cell balancing with the efficiency of charging and idle modes of $99 \%$ and $99.4 \%$ respectively. Finally, in testing the integrated system, the BMS can maintain the performance of the Microgrid with bus voltage and battery current parameters in various SoC conditions and generator voltage fluctuations, even though there are high voltage transients.
\end{abstract}

\begin{tabular}{|c|c|}
\hline Informasi Artikel & Abstrak \\
\hline $\begin{array}{l}\text { Kata kunci: Bidirectional } \\
\text { Converter, Cell Balancing, } \\
\text { Hardware-in-the-Loop, } \\
\text { Mikrogrid DC, Sistem } \\
\text { Manajemen Baterai, }\end{array}$ & $\begin{array}{l}\text { Dalam sistem Mikrogrid yang mengandalkan pembangkit energi terbarukan, } \\
\text { salah satu sistem penyusun terpenting-nya ialah Sistem Baterai Penyimpan } \\
\text { Energi dikarenakan perannya yang vital untuk menjaga stabilitas Mikrogrid } \\
\text { dalam penyediaan daya ke beban. Namun untuk mengoperasikan baterai, } \\
\text { diperlukan sebuah Sistem Manajemen Baterai untuk memastikan baterai } \\
\text { beroperasi pada rentang kerja yang diinginkan, sehingga keandalan baterai } \\
\text { dapat terjaga. Untuk mengetahui perilaku Mikrogrid beserta BMS yang } \\
\text { dirancang telah sesuai dengan spesifikasi yang diinginkan, telah dirancang } \\
\text { Simulasi Hardware-in-the-Loop (HIL) menggunakan Simulink untuk memodelkan } \\
\text { Mikrogrid DC yang terdiri dari beberapa sub-sistem seperti: Pembangkit dan } \\
\text { beban yang dirancang secara ideal sebagai penguji, sebuah bidirectional buck } \\
\text { and boost converter dengan pengontrol PI, dan sebuah sistem baterai yang } \\
\text { dilengkapi Cell Balancing bertipe Switched Shunt Resistor, seluruhnya dikontrol } \\
\text { menggunakan algoritma BMS yang diimplementasikan pada Arduino. Dari hasil } \\
\text { pengujian, diperoleh HIL dapat berkomunikasi dengan QoS yang baik pada } \\
\text { berbagai input selama waktu cuplik Arduino memenuhi. Kemudian diperoleh } \\
\text { pengontrol PI dengan HIL mampu meningkatkan performansi converter dan juga } \\
\text { berhasil mengontrol cell balancing dengan efisiensi mode charging dan idle } \\
\text { masing-masing 99\% dan 99.4\%. Terakhir pada pengujian sistem terintegrasi, } \\
\text { BMS dapat menjaga performa Mikrogrid dengan parameter tegangan bus dan } \\
\text { arus baterai pada variasi kondisi SoC dan fluktuasi tegangan pembangkit, } \\
\text { meskipun terdapat transien tegangan yang tinggi. }\end{array}$ \\
\hline
\end{tabular}




\section{Pendahuluan}

Mikrogrid merupakan sistem distribusi daya terlokalisasi yang mampu berdiri sendiri dan dapat berjalan secara pararel dengan/ tanpa terhubung dengan jala-jala PLN. Salah satu kelebihan utama penggunaan sistem Mikrogrid yakni; menurunkan rugi-rugi daya transmisi, meningkatkan reabilitas dan kestabilan karena terpisah dengan grid sentral yang sarat disturbance, serta mampu meningkatkan integrasi sumber energi terbarukan seperti energi solar dan angin (Car et al., 2017). Khusus untuk sumber energi dari sel surya dengan sistem Mikrogrid DC, penggunaan sistem Mikrogrid DC mampu meningkatkan efisiensi dari sumber hingga 6-8 \%. Selain itu dengan tidaknya converter DC/AC ataupun AC/DC pada bagian distribusi, maka rugi-rugi konversi mampu ditekan dari rata rata $32 \%$ menjadi $10 \%$ (Winasis et al., 2018). Beberapa komponen penting penyusun sebuah sistem Mikrogrid ialah sisi pembangkitan energi listrik, converter tegangan, jala-jala utilitas, Mikrogrid Controller dan sistem penyimpan energi (Car et al., 2017). Melihat tren saat ini, dari semua komponen penyusun Mikrogrid sistem penyimpanan energi berbasis baterai menjadi lebih relevan dan sangat penting dengan meningkatnya penggunaan energi baru terbarukan seperti tenaga surya dan angin. Baterai menjadi krusial bagi sistem dikarenakan sumber energi terbarukan sangat fluktuatif dan intermittent (Kim et al., 2018). Dengan adanya baterai, maka kelebihan energi yang dihasilkan dapat tersimpan dan dapat digunakkan jika sistem pembangkitan tidak mampu memenuhi permintaan beban, atau dengan kata lain baterai menjadi penopang kestabilan grid.

Namun, baterai pun memiliki beberapa kekurangan. Baterai memiliki lifespan dan cycle yang terbatas, dan kedua hal ini terus berkurang akibat charging-discharging yang tidak dijaga sehingga merusak baterai, seperti mengalami over-charging dan over-discharging. Selain itu, temperatur, aging, dan self-discharge juga dapat mempengaruhi kinerja baterai dalam penyediaan daya. Untuk itulah, diperlukan apa yang disebut dengan Sistem Manajemen Baterai (BMS) guna tetap menjaga performansi baterai sekaligus menjaga lifespan dan cycle agar tidak terdegredasi, sehingga reabilitas Mikrogrid dapat terjaga. Untuk merancang BMS yang baik, salah satu metode yang sering digunakkan dan low-cost ialah menggunakan simulasi untuk mensimulasikan baik perilaku baterai dan efek penerapan algoritma BMS terhadap performa baterai. Penelitian yang dilakukan selama ini ialah membuat simulasi hanya dalam software tanpa mempertimbangkan bagaimana performa perangkat keras seperti sistem kontroler. Untuk itu, simulasi Hardware-in-the-loop (HIL) mampu menjadi solusi untuk mensimulasikan kontroler pada berbagai variasi input dan algoritma dikarenakan kontroler seolah dapat berinteraksi dengan plant nyata yang pada dasarnya hanyalah berbentuk virtual atau simulasi.

Atas dasar hal itulah, pada penelitian ini akan dilakukan perancangan sebuah simulasi HIL yang akan berfokus untuk mensimulasikan sisi battery energy storage system yang terdiri dari sebuah sistem baterai, converter dan sistem manajemen baterai pada Mikrogrid DC. Sebagai sistem kontrol terbenam sistem manajamen baterai akan dipilih development board Arduino, hal ini dikarenakan selain harganya yang terjangkau dibandingkan DSP ataupun FPGA, juga masih minimnya penelitian mengenai HIL berbasis Arduino hingga saat ini (Biswas et al., 2018). Sehingga dengan dilakukannya penelitian ini, diharapkan akan menjadi pembuka potensi penelitian lebih lanjut dan terjangkau untuk dilakukan pada penelitian yang akan datang.

\section{Deskripsi Sistem}

Penelitian ini dilakukan dengan perancangan sistem Mikrogrid yang terdiri dari: pembangkit, beban, converter, baterai dan ssitem manajemen baterai. Sistem manajemen baterai akan diimplementasikan pada Arduino Mega 2560, sementara sub-sistem lain akan diimplementasikan pada Matlab-Simulink. Setelah dilakukan perancangan maka selanjutnya sistem akan diuji dengan variasi parameter dan pengambilan data.

\subsection{Perancangan Simulasi Hardware-in-the-Loop}

Set-up percobaan simulasi HIL menggunakan model plant yang akan disimulasikan pada Simulink Environment sementara embedded system control akan diimplementasikan menggunakan Arduino Development Board dengan jenis Arduino Mega 2560 Rev3. Agar antara Arduino dan Simulink dapat berkomunikasi dengan protokol USART, digunakan library Instrument Control dengan protokol komunikasi serial. Tampilan dari sub-sistem komunikasi data antara Simulink dan Arduino dapat dilihat pada Gambar 1.

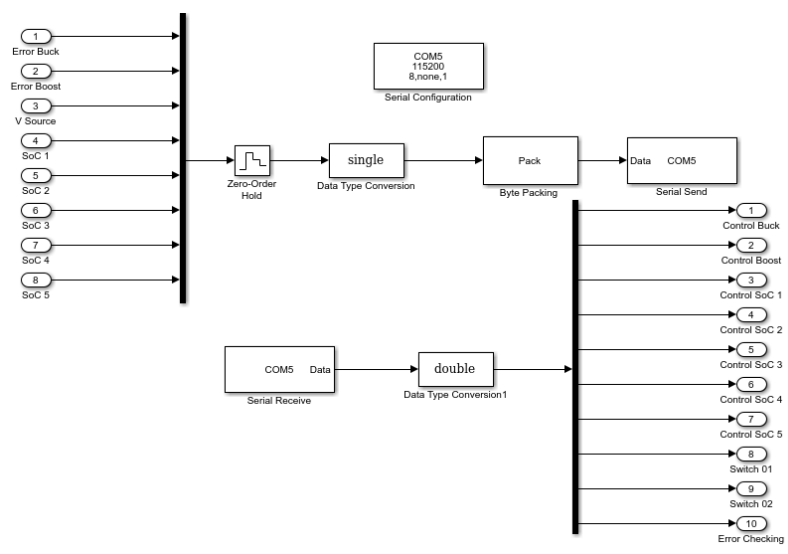


Gambar 1. Tampilan blok sub-sistem komunikasi Arduino-Simulink.

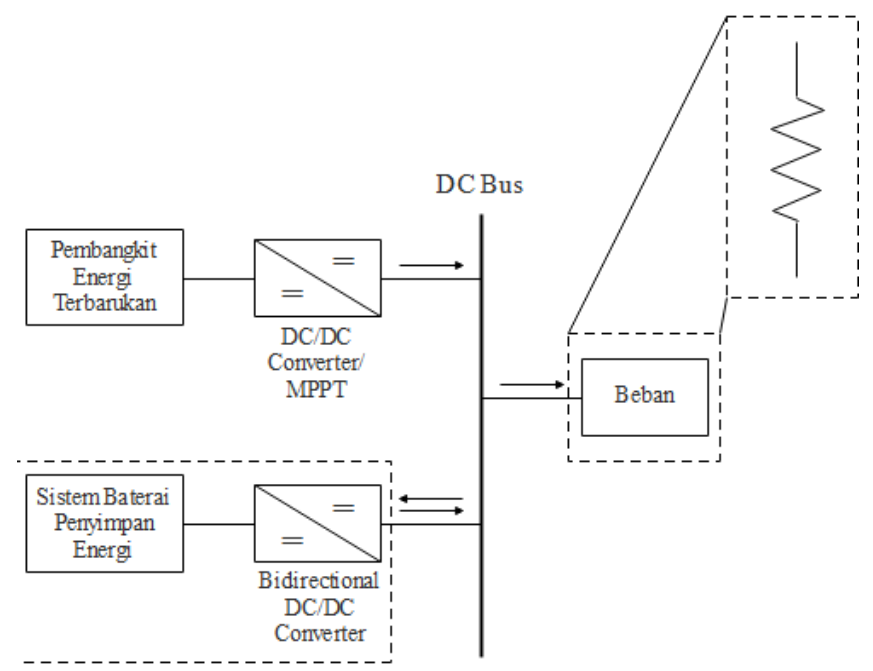

Gambar 2. Topologi Mikrogrid DC yang diajukan.

Blok pengiriman data dapat dibagi kedalam tiga bagian, yakni bagian pengiriman data, penerima data, serta konfigurasi komunikasi serial. Pengiriman data terdiri dari: Zero-Order Hold berfungsi mengatur laju pengiriman data, data type conversion berfungsi merubah tipe data yang akan dikirimkan ke tipe data 'single', byte packing berfungsi untuk mengkonversi sejumlah sinyal yang masuk menjadi sebuah vektor, dan serial send untuk pengiriman byte data. Adapun pada bagian penerima terdiri dari: Serial Receive untuk menerima data ASCII yang dikirim oleh Arduino dan sebuah data type conversion untuk diconvert ke tipe data 'double'. Adapun bagian konfigurasi berfungsi untuk mengatur berbagai parameter seperti baudrate dan port. Baudrate yang digunakan yakni sebesar $115200 \mathrm{bps}$, sementara simulasi secara keseluruhan dilakukan dengan fixed-step dengan besar waktu step $5 \times 10^{-6}$.

\subsection{Perancangan Mikrogrid}

Mikrogrid pada penelitian ini akan dibagi kedalam beberapa sub-bagian dimana pada penelitian ini, terdapat baterai, DC/DC bidirectional converter, serta sistem manajemen baterai. Adapun pembangkit dan beban akan menjadi sub-sistem pendukung penelitian pada tahap pengujian dan validasi sistem penyimpanan energi baterai yang telah dirancang. Topologi Mikrogrid yang diajukan pada penelitian ini dapat dilihat pada Gambar 2.

Pada Gambar 2, topologi yang digunakkan yakni Mikrogrid DC islanded dengan beban serta pembangkit energinya adalah tegangan DC. Pada penelitian ini, fluktuasi daya yang dibangkitkan pembangkit disimulasikan menyerupai pembangkit tenaga surya yang telah dilengkapi MPPT, yakni terjadi variasi tegangan akibat perubahan titik kerja dari panel surya. Hal ini pun dapat diterapkan secara general terhadap pembangkit energi jenis lain. Sementara untuk beban DC akan ditetapkan konstan sebesar $1 \Omega$ yang terhubung dengan DC bus yang dijaga pada $400 \mathrm{~V}$. Adapun bagian utama penelitian ini ada pada sistem baterai penyimpan energi. Pada sub-sistem ini, terdapat sebuah bidirectional buck and boost converter yang akan mengendalikan aliran daya antara baterai dan grid, sistem baterai dengan 5 cell serta sebuah sistem cell balancing yang akan dibahas pada sub-bab selanjutnya.

\subsection{Spesifikasi dan Perancangan Sistem Baterai}

Pada penelitian ini baterai Lithium-ion menjadi pilihan dikarenakan densitas energi yang tinggi dan menjadi tren perkembangan baterai saat ini dan di masa yang akan datang. Pada penelitian ini, akan digunakan model baterai LiFePO4 produksi Relion 51.2 V dan 200 Ah (RB48V200), dengan spesifikasi dapat dilihat pada referensi (Relion, 2021). Spesifikasi utama baterai ini dapat dilihat pada Tabel 1 dibawah.

Tabel 1. Tabel spesifikasi utama baterai.

\begin{tabular}{cc}
\hline Parameter & Nilai \\
\hline Tegangan Nominal & $51.2 \mathrm{~V}$ \\
Kapasitas Nominal & $200 \mathrm{Ah}$ \\
Arus Discharge Nominal & $40 \mathrm{~A}(0.2 \mathrm{C})$ \\
Tahanan Dalam & $\leq 50 \mathrm{~m} \Omega$ \\
Tegangan Cut-off & $40 \mathrm{~V}$ \\
Tegangan Kapasitas Penuh & $55 \mathrm{~V}$ \\
Kapasitas Tegangan Nominal & $150 \mathrm{Ah}$ \\
Tegangan Titik Eksponensial & $52.611 \mathrm{~V}$
\end{tabular}


Fathir M., Iskandar R. F., dan Fathonah I. W., Simulasi Hardware-in-the-Loop untuk Li-ion Battery Management System pada Mikrogrid DC, Journal of Energy, Material, and Instrumentation Technology, Vol. 2 No. 3, 2021

\begin{tabular}{cc}
\hline Parameter & Nilai \\
\hline Kapasitas Titik Eksponensial & $2.62 \mathrm{Ah}$ \\
\hline
\end{tabular}

Dengan memasukan semua parameter pada Tabel 2.1 ke model Generic Battery pada Simulink, maka akan diperoleh kurva dan persamaan Modified Shepherd Model disertai kurva karakteristik dischargenya seperti yang dapat dilihat pada Gambar 3.

\subsection{Perancangan Algoritma BMS}

Secara garis besar, logika pensaklaran dan aliran daya diatur oleh Tegangan Bus (VBus) dan SoC baterai. Tegangan kerja bus akan diregulasi pada nilai $400 \pm 5 \% \mathrm{~V}$, sehingga apabila terjadi penurunan daya pada pembangkit yang berimplikasi pada penurunan tegangan bus, maka besar perubahan tegangan akan dikompensasi oleh baterai sehingga tegangan bus akan kembali pada tegangan kerjanya. Sementara pada baterai, besar SoC akan dijaga pada nilai antara $20 \%$ - 90\%, dimana diluar nilai itu maka baterai akan diputus dari grid dan tidak akan terjadi charging maupun discharging. Gambar 4 menggambarkan diagram alir algoritma yang dirancang.

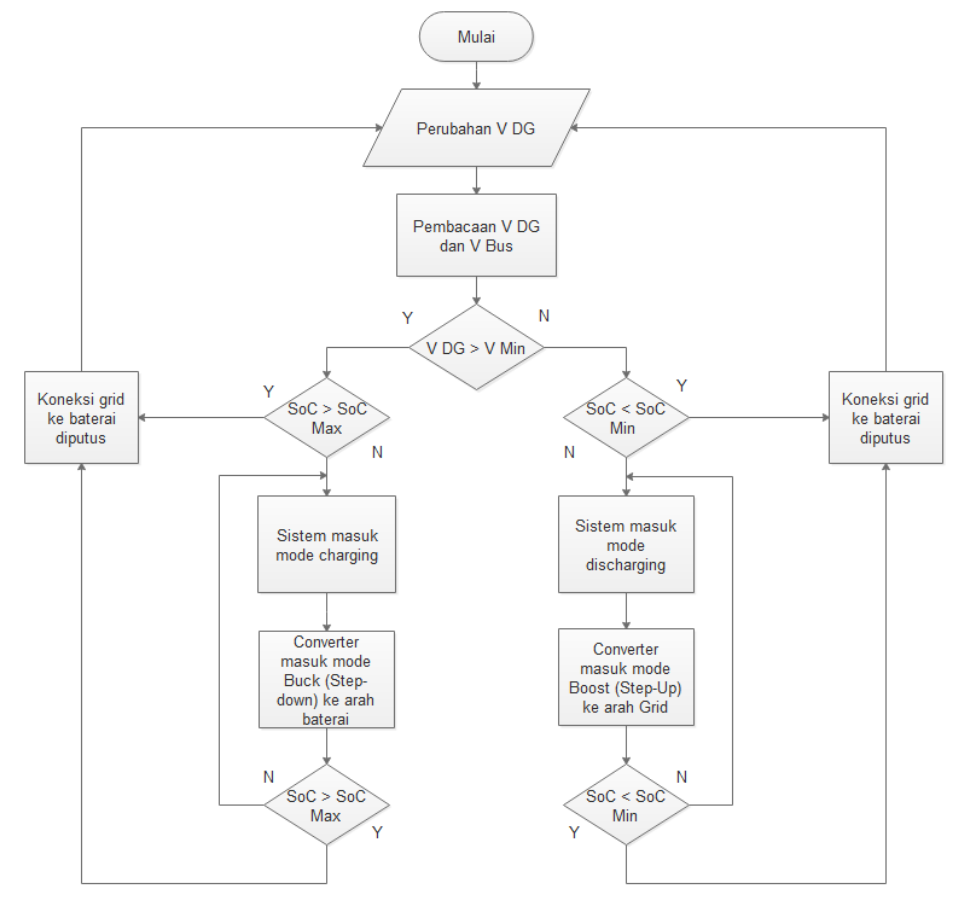

Gambar 4. Diagram Alir Algoritma utama BMS yang diajukan.

\subsection{Spesifikasi dan Perancangan Bidirectional Converter}

Bidirectional DC/DC Converter berfungsi sebagai interface yang akan mengatur aliran daya dan regulasi tegangan maupun arus antara grid dengan baterai. Pada penelitian ini, dipilih converter dengan tipe Bidirectional Buck and Boost Converter dengan pertimbangan kompensasi yang baik antara kerumitan topologi, sistem kontrol dan spesifikasi yang diinginkan. Adapun desain Converter dapat dilihat pada Gambar 5 dibawah.

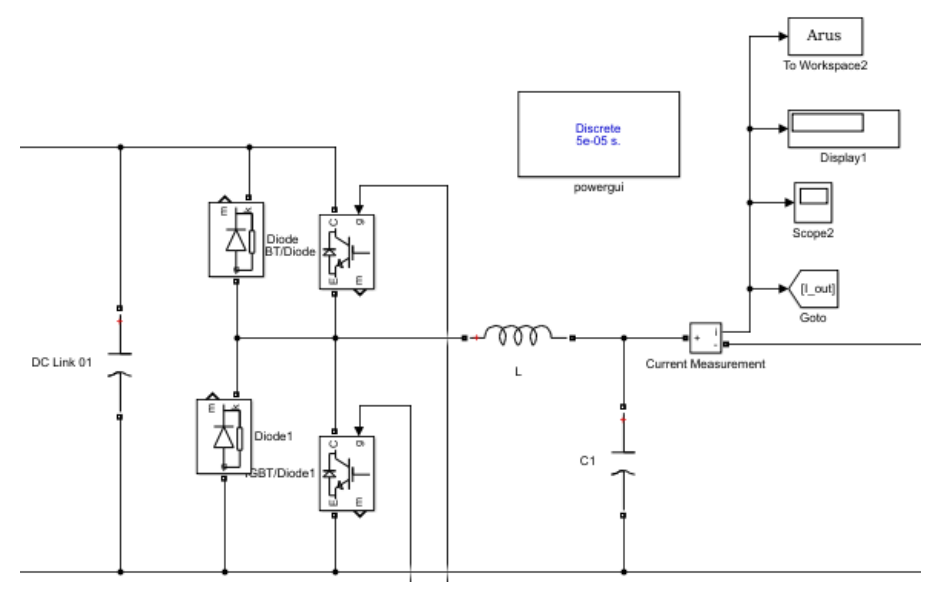


Gambar 5. Rancangan Bidirectional Buck-Boost converter yang diajukan.

Pada penelitian ini, Bidirectional Buck-Boost Converter dirancang pada frekuensi pensaklaran sebesar $5 \mathrm{kHz}$. Nilai ini didapat sebagai kompensasi antara durasi simulasi dan kemampuan Arduino yang cukup terbatas dalam pengolahan dan komunikasi data. Adapun duty cycle ditentukan berada pada rentang $0-0.8$. Nilai frekuensi dan duty cycle ini serta berbagai nilai variabel yang telah ditentukan pada sub-bagian model Mikrogrid dan Baterai akan menjadi dasar untuk menentukan nilai-nilai komponen elektronik pada Bidirectional Buck-Boost Converter dengan persamaan yang digunakan berasal dari referensi (Plotnikov \& Atamankin, 2019). Untuk induktor pada mode buck dan boost, digunakan persamaan 1 dan 2 .

$$
\begin{aligned}
& L_{\text {Buck }}=\frac{\left(V_{\text {Bus }}-V_{\text {Baterai }}\right) D_{\text {Max }}}{\Delta i_{L} f_{\text {sw }}} \\
& L_{\text {Boost }}=\frac{V_{\text {Bus }}\left(1-D_{\text {Max }}\right) D_{\text {Max }}}{\Delta i_{L} f_{\text {Sw }}}
\end{aligned}
$$

Berdasarkan referensi (Plotnikov \& Atamankin, 2019), besar osilasi arus $\Delta i_{L}$ dijaga pada rentang maksimum sebesar 5\% dari besar arus maksimum, sehingga besar induktansi dapat diperoleh dari masing masing mode. Berdasarkan beberapa variabel yang telah diperoleh sebelumnya, dipilih nilai induktor terbesar berasal dari kalkulasi buck sebesar $4.6 \mu \mathrm{H}$. Agar terpenuhi mode konduksi kontinu (CCM), nilai induktor haruslah $25 \%$ lebih tinggi dari nilai hasil kalkulasi, sehingga dipilih nilai sebesar $5.8 \mu \mathrm{H}$. Adapun untuk nilai kapasitor dapat dilihat pada persamaan 3 dan 4 .

$$
\begin{gathered}
C_{\text {Buck }}=\frac{I_{\text {Charging }} D_{\text {Min }}\left(1-D_{\text {Min }}\right)}{\Delta V_{\text {Baterai }} f_{\text {Sw }}} \\
C_{\text {Boost }}=\frac{I_{\text {Load }} D_{\text {Max }}}{\Delta V_{\text {Bus }} f_{\text {Sw }}}
\end{gathered}
$$

Dari hasil kalkulasi diperoleh nilai kapasitansi buck sebesar $8.1 \mathrm{mF}$ dan boost sebesar $6.4 \mathrm{mF}$. Untuk alasan keamanan, diambil nilai sebesar $9 \mathrm{mF}$ untuk Buck dan $7 \mathrm{mF}$ untuk Boost.

\subsection{Perancangan Cell Balancing}

Cell Balancing merupakan rangkaian yang berfungsi untuk memastikan bahwa SoC dari setiap cell baterai tidak terjadi perbedaan yang signifikan dan mengurangi kapasitas serta umur pemakaian baterai. Pada penelitian ini, cell balancing yang dipilih adalah kategori pasif, dengan tipe switched shunting resistor. Pemilihan ini karena kesederhanaan mekansime balancing berdasarkan disipasi daya pada resistor serta jumlah switch yang harus dikontrol relatif cukup sedikit dibandingkan dengan kategori aktif, sehingga cocok untuk embedded system yang terbatas kemampuannya seperti Arduino. Adapun diagram alir algoritma cell balancing ini dapat dilihat pada Gambar 7 dibawah.

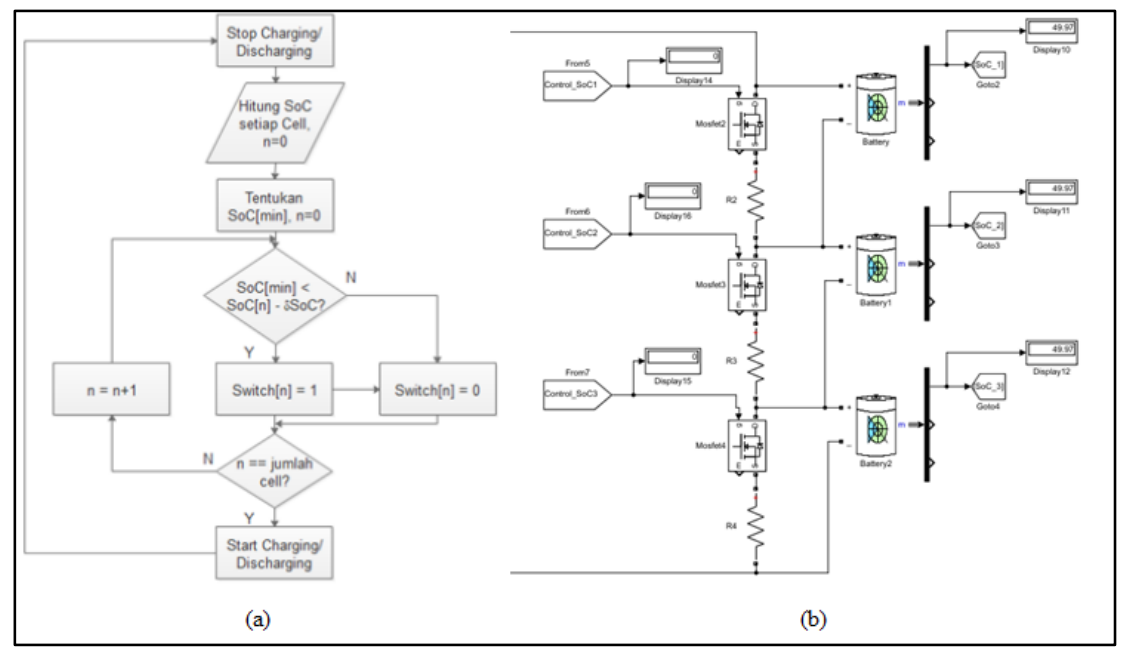

Gambar 7. (a) Diagram Alir algoritma cell balancing dan (b) Cell Balancing dirancang pada Simulink.

Pada diagram alir 6(a), cell balancing diinisiasi beberapa variabel baru, yakni: SoC minimum (SoC[min]), selisih minimum SoC $(\delta S o C)$ dan jumlah cell $(n)$. SoC $[\mathrm{min}]$ merupakan nilai SoC terendah diantara susunan seri dari cell dan $\delta S o C$ merupakan besar selisih yang diperbolehkan antara SoC cell lain dengan SoC cell terendah. Dengan algoritma diatas, maka cell dengan SoC yang lebih besar dari selisih yang diperbolehkan akan diturunkan dengan mengaktifkan saklar sehingga energi dari cell akan terdisipasi pada hambatan. Pada penelitian ini jumlah cell yang digunakan sebanyak 3 dan $\delta S o C$ sebesar $0.1 \%$. Adapun desain skematik sistem cell balancing beserta baterai ini dapat dilihat pada Gambar 6(b). Pada sistem diatas, Mosfet digunakan sebagai perangkat saklar yang dikendalikan 
Fathir M., Iskandar R. F., dan Fathonah I. W., Simulasi Hardware-in-the-Loop untuk Li-ion Battery Management System pada Mikrogrid DC, Journal of Energy, Material, and Instrumentation Technology, Vol. 2 No. 3, 2021

oleh sinyal kontrol, dimana sinyal kontrol ini berasal dari embedded system. Untuk kalkulasi besar hambatan yang akan digunakkan, diinginkan arus yang mengalir pada resistor bleeder adalah sebesar $C / 100$ untuk hasil optimal antara waktu balancing dan efisiensi (Amin et al., 2017). Karena kapasitas baterai yang dipilih sebesar 200 Ah, maka besar arus yang diinginkan yakni 2A. Dengan tegangan nominal baterai $51.2 \mathrm{~V}$, maka diperoleh resistansi yang diinginkan menggunakan Hukum Ohm sebesar 25.6 $\Omega$. Untuk mengetahui performansi efisiensi energi dari cell balancing, maka digunakkan persamaan (5) dibawah.

$$
\eta=\frac{E_{\text {Masuk }}-E_{\text {Terbuang }}}{E_{\text {Masuk }}} \times 100 \%
$$

\section{Hasil Dan Pembahasan}

Pada bagian ini, setiap sub-sistem akan diuji secara individual untuk selanjutnya diuji secara terintegrasi. Terdapat dua pengujian yang akan dilakukan yakni pengujian cell balancing dan sistem terintegrasi dengan pengujian pada kondisi normal dan variasi SoC diluar kondisi normal.

\subsection{Pengujian Cell Balancing}

Pada pengujian ini, nilai SoC beberapa cell akan dinaikkan secara acak untuk kemudian dilihat pengaruh algoritma cell balancing terhadap baterai, lama waktu balancing setiap cell, serta estimasi energi yang terdisipasi pada resistor bleed pada dua keadaan yakni charging dan idle. Untuk kebutuhan simulasi ini, besar kapasitas baterai akan diturunkan skalanya 1/200 kali dari kapasitas awal menjadi 1 Ah untuk memperpendek waktu simulasi. Selain itu, berdasarkan hasil yang diperoleh pada Sub-bab 4.1, waktu cuplik Arduino dinaikkan menjadi $0.05 \mathrm{~s}$ untuk meminimalisir error. Gambar 11 menunjukan kurva nilai SoC setiap cell baterai saat mode charging dan idle.

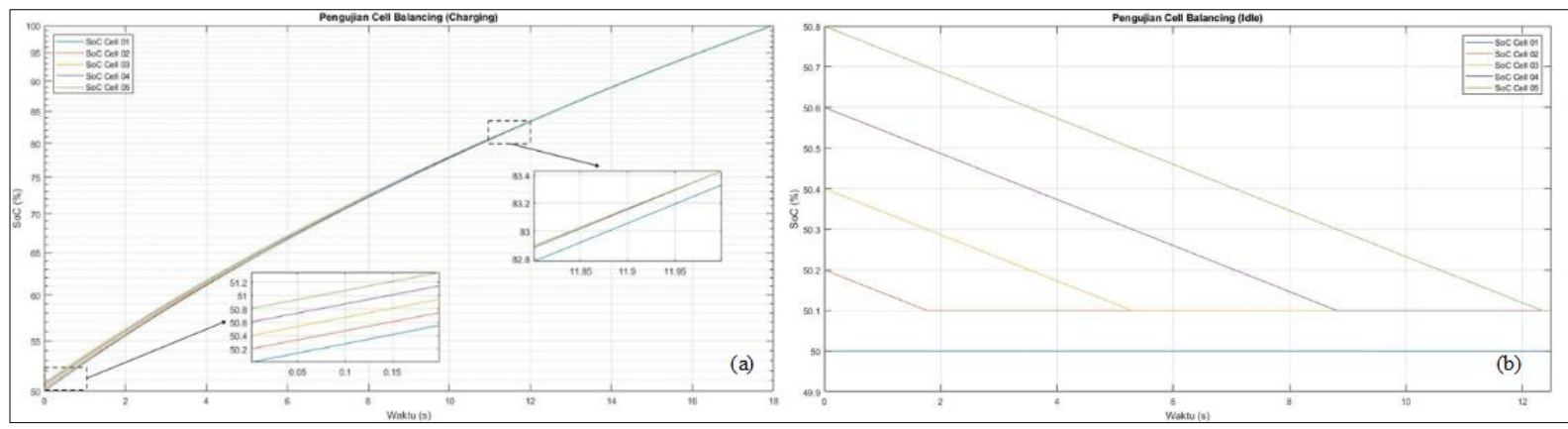

Gambar 11. Kurva SoC (a) Dalam kondisi charging dengan sumbu y dalam skala log dan (b) dalam kondisi idle

Pada pengujian ini, SoC awal setiap cell divariasikan sebesar $0.2 \%$ dengan nilai terendah $50 \%$ dan arus charging dijaga konstan pada 100 A. Dengan besar perbedaan terkecil SoC yang diperbolehkan adalah $0.1 \%$, algoritma yang diimplementasikan telah berhasil menjaga SoC setiap cell dalam rentang yang diinginkan. Berdasarkan hasil simulasi yang telah dilakukan penskalaan beberapa parameter, diperoleh waktu yang dibutuhkan untuk seluruh cell mencapai keadaan setimbang pada rentang $0.1 \%$ dari nilai minimum adalah sebesar $11.997 \mathrm{~s}$. Dengan mengembalikan nilai skala kapasitas baterai, maka diperoleh waktu yang dibutuhkan untuk seluruh cell setimbang adalah $2399.4 \mathrm{~s}$. Kemudian Gambar 11 (b) adalah hasil pengujian pada kondisi idle.

Pada pengujian idle ini, variasi cell dan SoC terendah persis sama dengan pengujian proses charging, namun dengan kondisi tidak charging dan discharging. Pada pengujian ini, seluruh cell mampu balancing hingga mencapai rentang $\delta$ SoC sebesar $0.1 \%$. Berdasarkan hasil simulasi, seluruh cell mampu setimbang dalam rentang waktu $12.344 \mathrm{~s}$, atau dengan mengembalikan skala kapasitas baterai akan didapat waktu selama $2468.8 \mathrm{~s}$ atau 41 menit. Rincian lama waktu balancing setiap cell pada kedua mode dapat dilihat pada Tabel 2 dan 3 dibawah.

Tabel 2. Lama waktu balancing dalam keadaan charging

\begin{tabular}{ccccc}
\hline Cell Ke- & SoC Awal (\%) & SoC Akhir Setimbang (\%) & SoC Rata-rata (\%) & Waktu Balancing \\
\hline 01 & 50 & - & - & - \\
02 & 50.2 & 55.0 & 52.583 & 350.6 \\
03 & 50.4 & 64.6 & 57.500 & 1044.2 \\
04 & 50.6 & 74.1 & 62.531 & 1728.2 \\
05 & 50.8 & 83.4 & 67.114 & 2399.4
\end{tabular}

Tabel 3. Lama waktu balancing dalam keadaan idle

\begin{tabular}{ccccc}
\hline Cell Ke- & SoC Awal (\%) & SoC Akhir Setimbang (\%) & SoC Rata-rata (\%) & Waktu Balancing \\
\hline 01 & 50 & - & - & - \\
02 & 50.2 & 50.1 & 50.150 & 352.6 \\
03 & 50.4 & 50.1 & 50.249 & 1058.2 \\
04 & 50.6 & 50.1 & 50.350 & 1762.8
\end{tabular}




\begin{tabular}{ccccc}
\hline Cell Ke- & SoC Awal (\%) & SoC Akhir Setimbang (\%) & SoC Rata-rata (\%) & Waktu Balancing \\
\hline 05 & 50.8 & 50.1 & 50.449 & 2468.8
\end{tabular}

Selanjutnya akan dianalisis rugi-rugi energi yang terjadi pada metode diatas. Berdasarkan data Bab 2, nilai tegangan nominal baterai sebesar 51.2 V dan resistansi $25.6 \Omega$ menghasilkan daya disipasi setiap resistor bleed sebesar 102.4 W. Berdasarkan data disipasi daya serta lama waktu balancing pada Tabel 2 dan 3, maka diperoleh energi yang terdisipasi pada setiap cell pada kedua mode seperti yang dapat dilihat pada Tabel 4 dibawah.

Tabel 4. Lama waktu balancing dalam keadaan charging dan idle

\begin{tabular}{ccc}
\hline Cell Ke- & Disipasi Energi Charging (Wh) & Disipasi Energi Idle (Wh) \\
\hline 02 & 9.973 & 10.029 \\
03 & 29.702 & 30.099 \\
04 & 49.158 & 50.142 \\
05 & 68.250 & 70.224 \\
Total & 157.083 & 160.494
\end{tabular}

Berdasarkan hasil Tabel 2 dan 3, dapat dilihat bahwa dengan menggunakan metode Switched Shunting Resistor dengan pemilihan besar resistor seperti pada Bab 2 menghasilkan lama waktu balancing yang relatif lama untuk perbedaan SoC yang tidak signifikan, namun energi yang terdisipasi relatif kecil. Hal ini dapat dibuktikan berdasarkan nilai efisiensi energi mengacu pada persamaan (5) sehingga didapat hasil seperti dibawah,

$$
\begin{gathered}
\eta=\frac{E_{\text {Masuk }}-E_{\text {Terbuang }}}{E_{\text {Masuk }}} \times 100 \%=\frac{V_{\text {Baterai }} I_{\text {Charging }} t_{\text {Balancing }}-\sum E_{\text {Terbuang }}}{V_{\text {Baterai }} I_{\text {Charging }} t_{\text {Balancing }}} \times 100 \%=99.0 \% \\
\eta=\frac{E_{\text {Masuk }}-E_{\text {Terbuang }}}{E_{\text {Masuk }}} \times 100 \%=\frac{\sum \text { SoC } \cdot V_{\text {Cell }} C_{\text {Cell }}-\sum E_{\text {Terbuang }}}{\sum S o C \cdot V_{\text {Cell }} C_{\text {Cell }}} \times 100 \%=99.4 \%
\end{gathered}
$$

Dari hasil diatas, didapat bahwa efisiensi energi pada cell balancing untuk baterai yang berada dalam mode idle sedikit lebih tinggi dibandingkan saat mode charging. Hal ini terjadi dikarenakan saat mode charging, tegangan cell meningkat dengan meningkatnya SoC Cell sehingga arus bleed sedikit lebih tinggi. Hal ini juga dapat menjelaskan mengapa rata rata $\mathrm{SoC}$ dan waktu balancing pada mode charging perlahan menurun sementara pada idle relatif linier.

\subsection{Pengujian Sistem Terintegrasi}

Setelah setiap sistem yang telah dirancang diuji dan memenuhi spesifikasi yang diinginkan pada sub-bab sebelumnya, maka terakhir akan diuji setelah seluruh sub-sistem terintegrasi. Sistem secara keseluruhan dapat dilihat pada Gambar 12 .

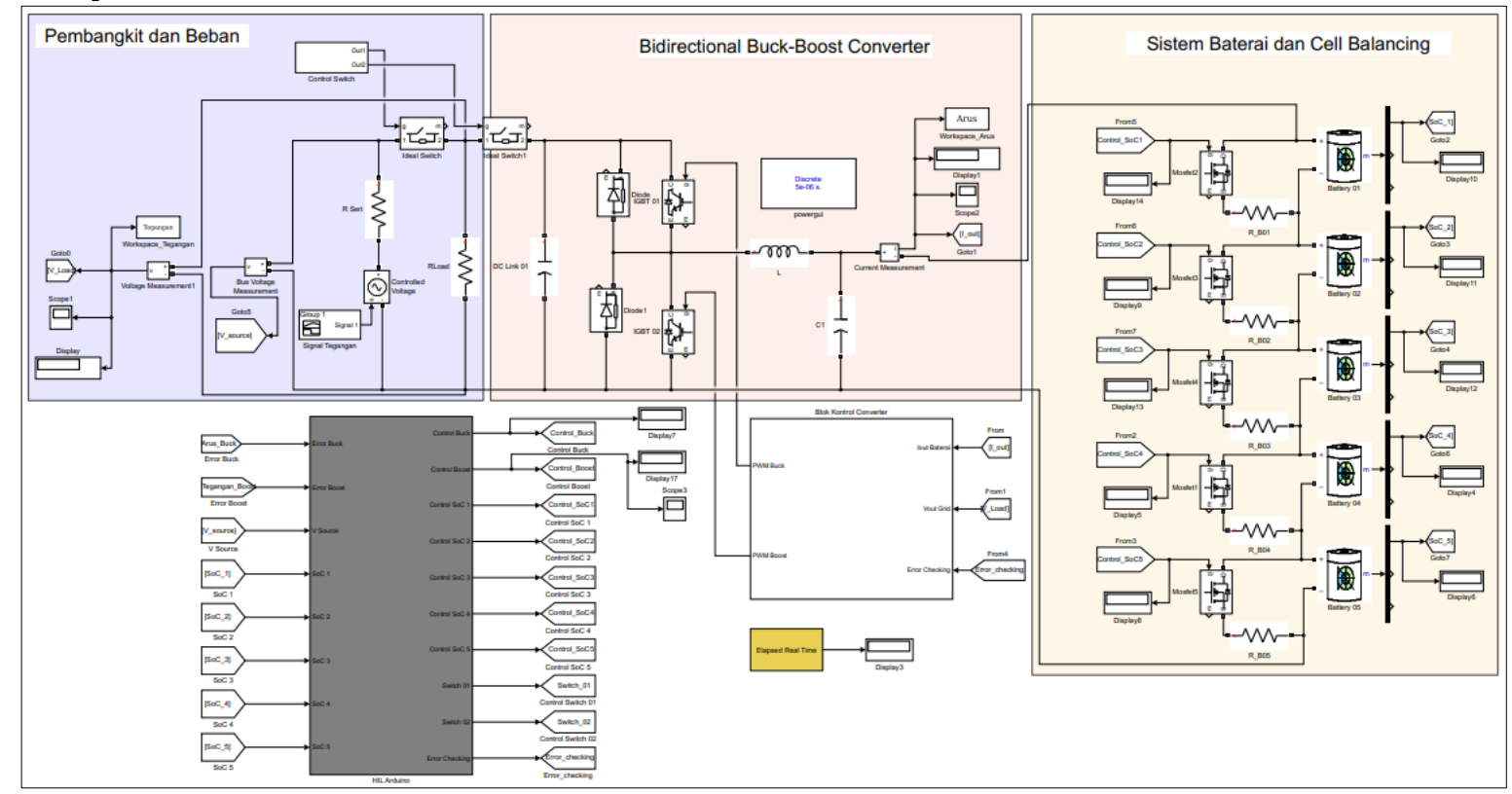

Gambar 12. Skema rangkaian Simulasi keseluruhan.

Simulasi akan dilakukan dengan waktu cuplik Arduino dinaikkan menjadi $0.2 \mathrm{~s}$ dikarenakan jumlah input data yang akan ditransfer sebesar 8 (Tegangan pembangkit, tegangan bus, arus baterai, SoC cell) dan yang diterima hingga 10 data (Duty Cycle Buck dan Boost, saklar kontrol SoC cell, saklar kontrol aliran daya dan sinyal untuk error checking). Untuk menguji sistem terintegrasi ini, variable tegangan pembangkit dan SoC akan divariasikan pada kasus-kasus ekstrim untuk kemudian dianalisis respon tegangan bus, arus baterai, SoC baterai dan state dari 
Fathir M., Iskandar R. F., dan Fathonah I. W., Simulasi Hardware-in-the-Loop untuk Li-ion Battery Management System pada Mikrogrid DC, Journal of Energy, Material, and Instrumentation Technology, Vol. 2 No. 3, 2021

switch. Respon berupa grafik yang dihasilkan ini kemudian akan dibandingkan dengan spesifikasi yang diinginkan untuk kemudian ditarik kesimpulan apakah sistem yang dibangun telah memenuhi tujuan ataupun tidak.

\section{Kasus operasi normal $(20 \% \leq$ SoC $<90 \%)$}

Pada percobaan operasi normal, besar SoC sistem baterai akan berada pada rentang kerja normalnya yakni 20-90\% dengan besar tegangan pembangkit berubah-ubah untuk mensimulasikan pembangkit energi terbarukan seperti dapat dilihat pada Gambar 13. Tegangan berubah dengan nilai antara 0-400 V, dimana nilai tegangan pada saat $\mathrm{t}=0 \mathrm{~s}$ bernilai $0 \mathrm{~V}$ dan perlahan naik kemudian konstan pada $200 \mathrm{~V}$ dan mencapai maksimal pada $400 \mathrm{~V}$. Kemudian tegangan turun sejenak ke $350 \mathrm{~V}$ sebelum kembali ke $400 \mathrm{~V}$ dan akhirnya turun perlahan hingga $0 \mathrm{~V}$.

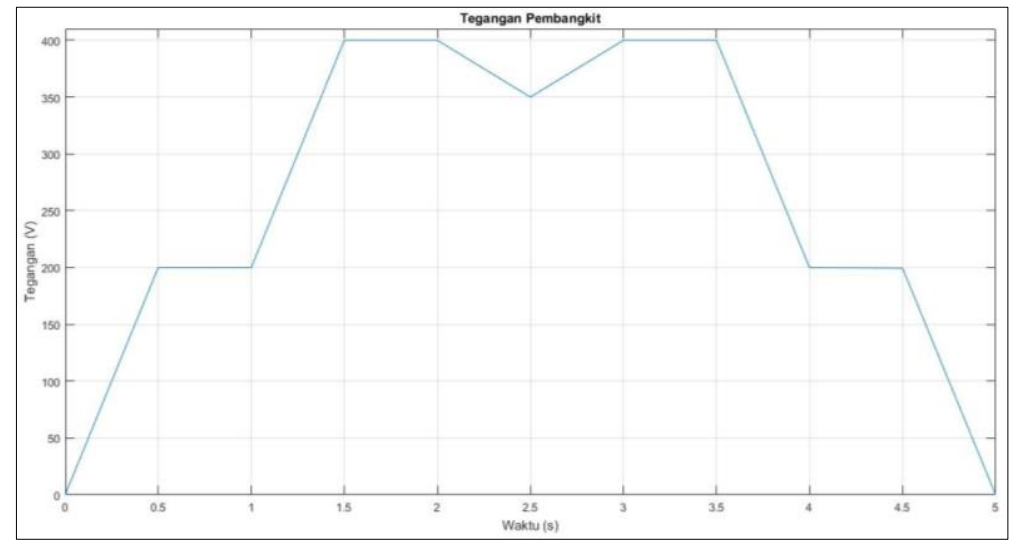

Gambar 13. Grafik fluktuasi tegangan sumber energi terbarukan.

Dari besar perubahan tegangan tersebut, kemudian Microgrid disimulasikan dalam rentang waktu $5 \mathrm{~s}$ hingga dihasilkan nilai tegangan bus, arus charging/ discharging baterai serta perubahan switch seperti yang dapat dilihat pada Gambar 14.

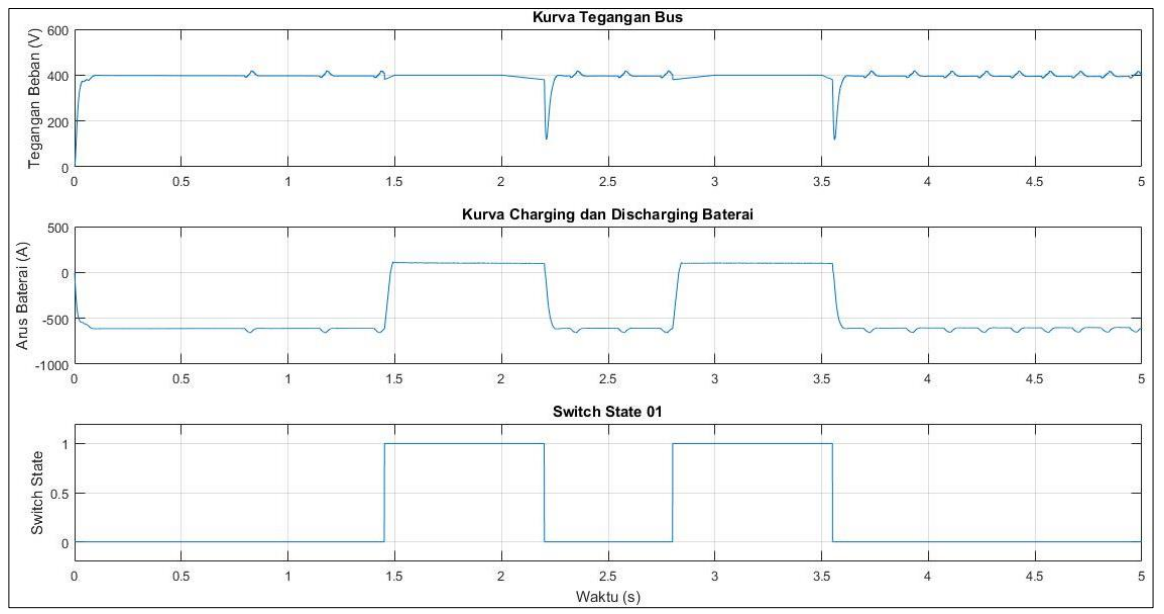

Gambar 14. Respon tegangan bus, arus charging dan discharging baterai serta keadaan switch sumber ke bus.

Dapat dilihat pada Gambar 14 baik tegangan bus, arus maupun switch state memiliki respon sesuai dengan yang diinginkan dengan konstanta PI untuk mode buck ialah $\mathrm{Kp}=10$ dan $\mathrm{Ki}=0.5$, serta mode boost $\mathrm{Kp}=0.2$ dan $\mathrm{Ki}=0.5$. Pada saat Microgrid mulai beroperasi, nilai tegangan masih dibawah rentang tegangan yang diinginkan $(400 \pm 20 \mathrm{~V})$ sehingga switch yang menghubungkan sumber ke bus dalam keadaan open, dan bus akan disupply oleh baterai yang berada dalam keadaan discharge. Adapun switch BESS ke bus selalu dalam keadaan open karena berada pada rentang kerja SoC baterai. Pada saat awal beroperasi, nilai tegangan berhasil mencapai setpoint $400 \mathrm{~V}$ dengan karakteristik responnya: overshoot $0 \%$, rise time $0.0257 \mathrm{~s}$, settling time $0.0807 \mathrm{~s}$ serta error steady-state $0.46 \%$. Riak tegangan yang timbul yakni sebesar $0.9 \%$ dengan rentang nilai diantara 396.43 400 V Adapun respon transien yang timbul pada $0.8 \mathrm{~s}, 1.5 \mathrm{~s}$ dan $1,4 \mathrm{~s}$ dikarenakan error dan loss data pada komunikasi, bukan dikarenakan respon terhadap sistem. Kemudian saat nilai tegangan sumber mencapai nilai $\geq 380 \mathrm{~V}$, state switch berubah dari ' 0 ' ke ' 1 ' atau 'closed' sehingga bus akan dicatu oleh sumber dan baterai berubah dari discharging ke 
mode charging. Respon arus charging ini memiliki nilai overshoot $15 \%$, nilai rise time (diukur dari 0 A) $0.008 \mathrm{~s}$, settling time $0.1313 \mathrm{~s}$ dan error steady-state $0.15 \%$. Besar riak yang timbul yakni $0.7 \%$ dengan rentang nilai antara 99.8 100.5 A. Namun, ketika terjadi penurunan tegangan sumber kembali dan state switch kembali pada kondisi 'open', terjadi gejala transien dimana nilai tegangan turun secara drastis hingga $120 \mathrm{~V}$ (undershoot $70 \%$ ) dan kembali stabil pada $400 \mathrm{~V}$ dengan clearing time $0.049 \mathrm{~s}$. Hal ini terjadi setiap kali switch kembali ke kondisi 'open' atau setiap baterai beralih dari mode charging ke discharging.

\section{Kasus operasi saat SoC baterai berada pada SoC maksimum ( $\geq 90 \%)$}

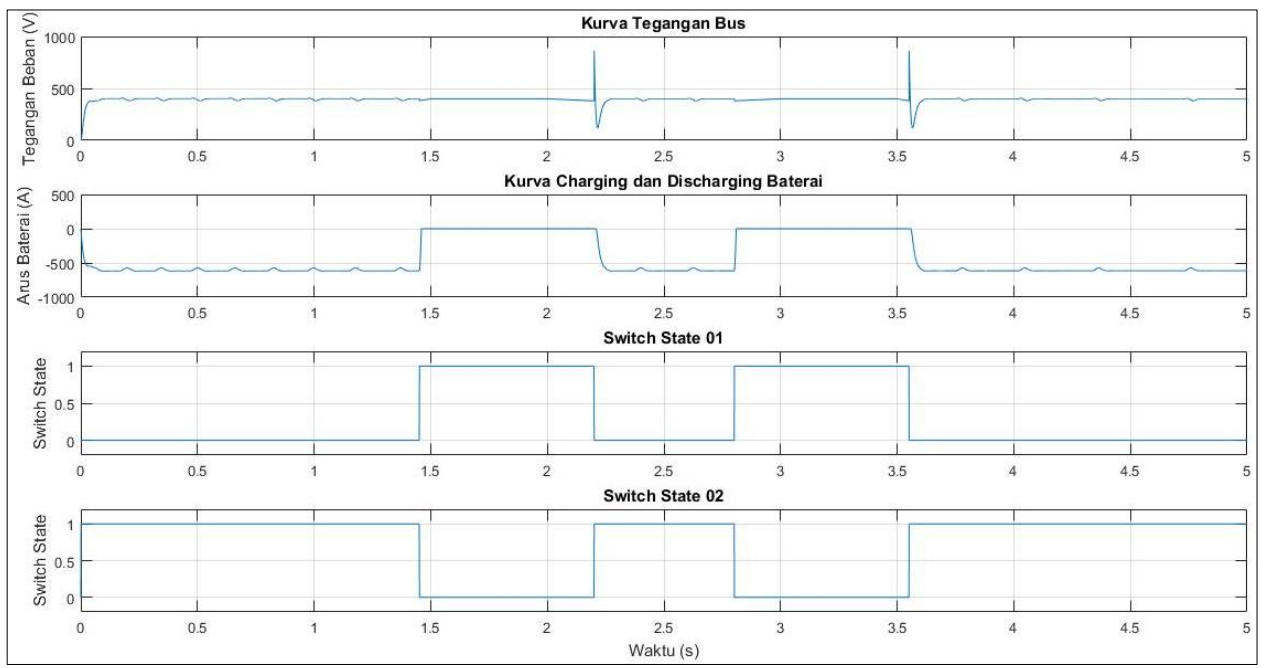

Gambar 15. Respon tegangan bus, arus charging dan discharging baterai serta keadaan switch sumber ke bus dan BESS ke bus.

Pada kasus ini, SoC baterai disimulasikan berada diatas SoC maksimum yang diperbolehkan yang telah ditentukan pada Algoritma BMS. Pada kondisi ini, baterai haruslah dalam keadaan idle saat sumber mampu menyupply beban dan discharging saat sumber tidak dapat memenuhi rentang tegangan yang diinginkan. Gambar 15 menunjukan respon tegangan bus, arus baterai, state switch sumber dan state switch dari bus ke BESS. Pada Gambar 15, respon arus dan tegangan pada saat awal Microgrid beroperasi persis saat operasi normal dengan switch sumber ke beban dalam keadaan open dan beban disupply oleh sistem baterai. Respon tegangan yang dihasilkan saat awal beroperasi pun serupa dengan besaran konstanta PI yang persis sama, namun terjadi pergeseran nilai error steady-state yakni sebesar $0.34 \%$ atau mengalami penurunan relatif kecil dibandingkan operasi normal. Adapun riak gelombang tegangan ialah sebesar 0.9\% berada pada rentang 399.6 403.19 V. Ketika tegangan pembangkit telah mencapai rentang kerja $\geq 380 \mathrm{~V}$, dikarenakan SoC baterai masih berada diatas nilai SoC maksimum yang diperbolehkan, maka switch yang menghubungkan baterai ke beban (Switch 02) akan langsung berubah dari state ' 1 ' ke ' 0 ' sehingga baterai masuk kondisi idle, dengan kata lain sumber energi terbarukan hanya mencatu beban saja. Pada kondisi ini tidak terdapat transien tegangan yang terjadi. Namun, ketika terjadi penurunan tegangan kembali pada pembangkit, switch state baterai ke beban kembali ke state ' 1 ' (closed) dan kemudian terjadi gejala transien tegangan hingga mencapai tegangan sebesar $862.9 \mathrm{~V}$ atau overshoot hingga $115 \%$ dan undershoot tegangan $120.8 \mathrm{~V}$ atau $69.8 \%$. Clearing time yang terjadi hingga tegangan kembali pada keadaan stabilnya yakni $0.079 \mathrm{~s}$. Hal ini pun kembali terjadi lagi saat perubahan state switch 02 dari ' 1 ' ke ' 0 ' atau open kedua kalinya dengan nilai overshoot, undershoot dan clearing time sama.

Kasus operasi saat SoC baterai berada pada SoC minimum $(<20 \%)$ 
Fathir M., Iskandar R. F., dan Fathonah I. W., Simulasi Hardware-in-the-Loop untuk Li-ion Battery Management System pada Mikrogrid DC, Journal of Energy, Material, and Instrumentation Technology, Vol. 2 No. 3, 2021

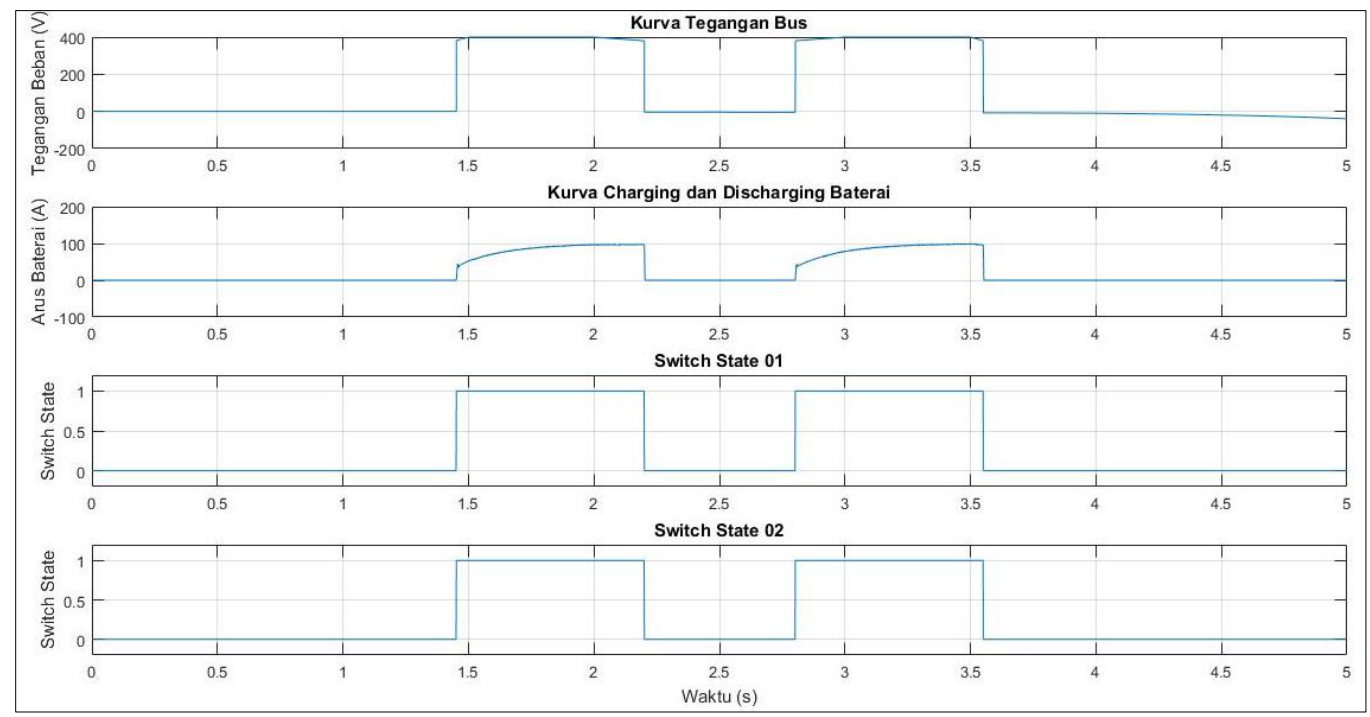

Gambar 16. Respon tegangan bus, arus charging dan discharging baterai serta keadaan switch sumber ke bus dan BESS ke bus.

Pada kasus ini, SoC baterai disimulasikan berada dibawah SoC minimum yang diperbolehkan yang telah ditentukan pada Algoritma BMS. Pada kondisi ini, baterai haruslah dalam keadaan charging saat sumber mampu menyupply beban dan baterai, serta dalam keadaan idle saat sumber tidak dapat memenuhi rentang tegangan yang diinginkan. Gambar 16 menunjukan respon tegangan bus, arus baterai, state switch sumber dan state switch dari bus ke BESS. Pada awal Microgrid beroperasi, baik tegangan yang belum memenuhi rentang tegangan kerja grid $(400 \pm 20$ V) dan SoC baterai yang berada pada batas bawah SoC minimum agar baterai dapat melakukan discharging mengakibatkan kondisi dimana beban tidak tersupply daya sama sekali atau blackout. Hal ini selalu terjadi jika tegangan pembangkit berada di bawah batas yang diinginkan. Adapun saat tegangan pembangkit berada pada rentang $400 \pm 20 \mathrm{~V}$, maka switch state 01 dan switch state 02 berpindah state dari ' 0 ' $\mathrm{ke}$ ' 1 ' atau closed, dimana pembangkit akan menyupply beban dan charging baterai. Adapun respon arus charging ini yakni overshoot $0 \%$, rise time $0.3245 \mathrm{~s}$, settling time $0.5258 \mathrm{~s}$ dan error steady-state yakni $1.975 \%$. Adapun riak arus yang terjadi adalah sebesar 1.93\% pada rentang nilai 97.06 98.99 A. Nilai yang sama juga didapat pada saat arus charging untuk kedua kalinya seperti yang dapat dilihat pada Gambar 16. Seluruh respon nilai tegangan dan arus hasil percobaan dirangkum pada Tabel 5 dibawah.

Tabel 5. Respon tegangan bus dan arus charging baterai pada berbagai kasus

\begin{tabular}{ccccccc}
\hline Kasus & Parameter & $\%$ OS $(\%)$ & $\mathrm{T}_{\text {Rise }}(\mathrm{s})$ & $\mathrm{T}_{\text {Settling }}(\mathrm{s})$ & $\mathrm{e}_{\mathrm{s}-\mathrm{s}}(\%)$ & Riak (\%) \\
\hline Normal & $\mathrm{V}_{\text {Bus }}$ & 0 & 0.0257 & 0.0807 & 0.4600 & 0.9000 \\
& I Charge & 15.000 & 0.008 & 0.1313 & 0.15 & 0.7 \\
SoC & $\mathrm{V}_{\text {Bus }}$ & 0 & 0.0257 & 0.0807 & 0.3400 & 0.9000 \\
$\geq 90 \%$ & I Charge $_{\text {SoC }}$ & $\mathrm{V}_{\text {Bus }}$ & \multicolumn{5}{c}{ Tidak ada pengisian arus baterai } \\
$<20 \%$ & I Charge & 0 & 0.3245 & 0.5258 & 1.9750 & 1.9300 \\
\hline
\end{tabular}

Berdasarkan hasil yang diperoleh pada Tabel 5, akan dibandingkan nilai setiap parameter (VBus dan ICharge) berdasarkan rancangan yang telah dibuat pada Bab 2. Berdasarkan datasheet [25], nilai overshoot yang terjadi saat arus charging dalam mode normal berada dalam batas aman charging $(<100 \mathrm{~A})$. Selanjutnya ialah riak baik VBus dan ICharge yang telah sesuai dengan batas rancangan, yakni $10 \%$ untuk tegangan dan $5 \%$ untuk arus. Respon waktu dan error steady-state yang dihasilkan pun sudah cukup baik, namun yang menjadi perhatian ialah menurunnya performansi respon arus saat SoC berada dibawah SoC minimum. Selain itu adanya transien tegangan yang sangat signifikan yakni undershoot $70 \%$ pada mode normal dan overshoot $115 \%$ pada saat SoC baterai diatas SoC maksimum harus ditangani dengan ditambahkan perangkat peredam transien pada bus Mikrogrid.

\section{Kesimpulan}

Berdasarkan simulasi yang telah dilakukan pada Matlab-Simulink ${ }^{\circledR}$ diperoleh kesimpulan sebagai berikut:

1. Telah berhasil dirancang dan dianalisis sebuah sistem baterai dan cell balancing pada kedua mode yakni charging dan idle berbasis simulasi HIL. Dari pengujian diperoleh waktu balancing untuk mode charging lebih cepat dari idle dengan efisiensi untuk mode charging adalah 99\% dan idle $99.4 \%$. Dari hasil ini dapat disimpulkan sistem yang dirancang memiliki efisiensi energi yang tinggi namun dengan waktu balancing yang relatif lama untuk perbedaan SoC yang tidak begitu signifikan;

2. Telah berhasil dirancang dan dianalisis sistem Mikrogrid terintegrasi berbasis simulasi HIL dengan variabel bebas tegangan sumber energi terbarukan dan variasi SoC. Dari hasil analisis diperoleh sistem telah bekerja sesuai dengan algoritma BMS yang dirancang dan memiliki performansi respon baik tegangan bus, 
arus baterai dan switch yang sangat baik. Namun terdapat gejala transien yang cukup signifikan terjadi pada pergantian mode dari charging dan discharging akibat pembuangan energi dari induktor dan kapasitor ke beban.

\section{Daftar Pustaka}

Amin, Ismail, K., Nugroho, A., \& Kaleg, S. (2017). Passive balancing battery management system using MOSFET internal resistance as balancing resistor. Proceeding - ICSEEA 2017 International Conference on Sustainable Energy Engineering and Application: \&quot;Continuous Improvement of Sustainable Energy for EcoMobility\&quot;, 2018-Janua, 151-155. https://doi.org/10.1109/ICSEEA.2017.8267701

Biswas, S. P., Hosain, M. K., \& Rahman, M. W. (2018). Real-time arduino based simulator enabled hardware-inthe-loop electric DC machine drive system. 5th IEEE Region 10 Humanitarian Technology Conference 2017, R10-HTC 2017, 2018-Janua(November 2020), 823-826. https://doi.org/10.1109/R10-HTC.2017.8289082

Car, M., Vasak, M., \& Lesic, V. (2017). Control of a buck-boost DC-DC power converter for microgrid energy storage. International Conference on Electical Drives and Power Electronics, 2017-October. https://doi.org/10.1109/EDPE.2017.8123267

Kim, D. K., Yoneoka, S., Banatwala, A. Z., \& Kim, Y. (2018). Handbook on Battery Energy Storage System (Issue December). https://www.adb.org/publications/battery-energy-storage-system-handbook

Plotnikov, I., \& Atamankin, G. (2019). Selecting Components for Bidirectional DC-DC Converter of Photovoltaic Power Supply System. Proceedings - 2019 IEEE Russian Workshop on Power Engineering and Automation of Metallurgy Industry: Research and Practice, PEAMI 2019, 64-69. https://doi.org/10.1109/PEAMI.2019.8915133

Relion. (2021). RB48V200. 20-21.

Winasis, Suroso, Prasetijo, H., \& A. K., A. N. (2018). Analisis Sistem Mikrogrid DC Photovoltaic Terhubung Jalajala. Seminar Nasional Teknik Elektro, 44-49. 